\begin{tabular}{c}
\hline Review of \\
ECONOMICS \\
and \\
INSTITUTIONS \\
\hline
\end{tabular}

\title{
Tangible and Intangible Capital and the Pattern of Specialisation in the EU
}

\author{
Ioannis Bournakis \\ Middlesex University
}

\author{
Michela Vecchi ${ }^{\varpi}$ \\ Middlesex University \& National Institute \\ of Economic and Social Research
}

\begin{abstract}
This paper investigates the determinants of specialisation in 7 European countries and 4 major industrial sectors in the last 20 years. Next to the impact of traditional factors such as productivity and the endowment of labour and capital, we look at the importance of accounting for capital heterogeneity, by distinguishing between ICT and non-ICT assets, and for intangible capital such as skills and R\&D. Our results show that intangible capital and innovation play an important part in increasing the value added shares of the Manufacturing sector while increasing investments in ICT have driven resources away from Manufacturing and towards the Service industry.
\end{abstract}

JEL classification: F11, F14, D24

Keywords: specialisation, value added shares, factor accumulation, TFP, ICT capital, R\&D, skills

We would like to thank Roger Vickerman, Maria Garcia Alonso, Rod Falvey, HansMartin Krozlig, Ian Marsh, Mary O'Mahon, Fabrizio Casalin, Francesco Venturini and an anonymous referee for useful comments and suggestions. We have also benefited from comments from the participants at the 11th ETSG meeting in Rome and the 2010 Scottish Economic Society Conference. All errors are the authors' sole responsibility.

\section{Introduction}

In one of the earliest discussions on patterns of specialisation, Clark (1957) emphasises the link between income spending and specialisation of production: at low income levels, a large share of income is spent on the consumption of inferior or normal goods. As income increases, consumption gradually shifts from inferior to superior goods. In a similar manner, countries at the initial stage of development are characterised by

$\triangle$ Corresponding author. Address: Middlesex University, Business School, Department of Economics and Statistics, Hendon Campus, London, NW4 4BT.

(Email: $\underline{\text { m.vecchi@mdx.ac.uk) }}$

\section{Recommended Citation}

Bournakis, I., Vecchi, M. (2010). Tangible and Intangible Capital and the Pattern of Specialisation in the EU. Review of Economics and Institutions, 1 (2), Article 3. doi: 10.5202/rei.v1i2.3. Retrieved from http://www.rei.unipg.it/rei/article/view/16 
relatively high shares of manufacturing production while, as countries develop further, they move away from manufacturing towards the production of services. This pattern has characterised the development of many European countries, which experienced a very fast pace of industrialisation since the end of the Second World War, followed by a decline in manufacturing production in the last three decades. Hence, deindustrialisation and specialisation can be analysed within a common framework.

The reasons behind the gradual decrease in the share of manufacturing are not always clear and the existing literature has put forward several possible causes. One explanation relies on the impact of external forces such as the growth of West-East trade, outsourcing and migration flows. However, internal factors such as productivity and factor endowment appear to play a relatively more important role (Rowthorn and Ramaswamy, 1999). Hence, the traditional forces of specialisation and international trade, summarised in the Ricardian and the Heckscher-Ohlin models, are gaining new impetus (Cadot et al., 2007).

Another strand of literature has investigated the importance of innovation on productivity performance and in particular the role of ICT and intangible assets (O'Mahony and Vecchi, 2005, 2009; Corrado et al., 2006). Empirical evidence has shown that in the US and to a lesser extent in Europe, increasing investments in ICT has gone hand in hand with increasing productivity, particularly in the service sector (O'Mahony and Van Ark, 2003). Intangible assets, such as R\&D and human capital, affect productivity by stimulating innovation and by facilitating the absorption of innovation developed elsewhere (Griffith et al., 2004). Much less investigated has been the issue of how ICT and intangible assets have affected the pattern of specialisation. In an economic environment where gains in competitiveness are an increasing function of technology, understanding this relationship is of crucial importance for Government policy and countries' performance. What is the relative importance of tangible and intangible assets in explaining countries' specialisation and international competitiveness?

The main objective of this paper is to answer this question by analysing the relationship between specialisation and countries' endowment of tangible and intangible capital, using data for 7 European Countries and 4 major national sectors of production. Firstly, our investigation will assess whether determinants suggested by the neoclassical economic theory can explain the increase (decrease) of the output share in services (manufacturing). We look at Ricardian forces (productivity) and Heckscher-Ohlin-Vanek (H-O-V) variables (factor endowments) as the key drivers of de-industrialisation. 
Our analysis adds to the existing literature firstly by accounting for different types of capital, namely ICT and non-ICT capital. Secondly, we look at the endowment of intangible factors. The latter are notoriously difficult to define and to measure. In our analysis, we evaluate the importance of intangible assets by introducing R\&D capital and skilled labour into a standard neoclassical model. Managerial practices and organisational changes are also important intangible assets and they are particularly linked to ICT investments (Bresnahan et al., 2002). Although a direct measure of organisational changes is not meaningful at the country level, the inclusion of ICT capital, next to a technology indicator, should reasonably account for their impact at the more disaggregate structure.

The sample of countries included in the analysis provides an interesting mixture of experiences in terms of technology development, institutional environment and sector of specialisation, despite being all in a well-defined geographical area (Europe). Our main results show that the availability of highly skilled workers and investments in ICT capital are the main drivers of the de-industrialisation process. Investments in R\&D and technology are the driving forces against de-industrialisation. We also find the presence of interesting cross-industry technology effects, suggesting the presence of spillovers within sectors.

The paper is organised as follows: section 2 presents the analytical framework, which is our basis for deriving the empirical specification. Section 3 discusses the data sources as well as the construction of the main variables used in the empirical analysis. Section 4 presents the econometric specification and section 5 presents our results. Section 6 concludes the paper and discusses possible policy implications.

\section{Hypotheses}

Our theoretical framework follows Dixit and Norman (1980) in specifying a neoclassical model of specialisation where national income is a function of factor endowments and final good prices. The income function is written as:

$$
Y=r(P, V)
$$

where $Y$ is national income, $P$ is a vector of prices and $V$ is a vector of national factor endowments. The function is homogeneous of degree one in $P$ and $V$. Under the assumptions of continuity and twice differentiability, the gradient of (1) with respect to prices is equal to the amount of output that maximises national income. Assuming that technology is identical across countries, international specialisation is 
driven by differences in $P$ and $V$. However, substantial evidence of crosscountry productivity differences (see among many others Dollar and Wolff, 1993; Harrigan, 1999; O'Mahony and van Ark, 2003) dictates that the effect of technology on the pattern of specialisation requires a more systematic treatment.

Trefler (1995) models technological differences as sector neutral and country-specific adjusting factor endowments in productivity units. Although this approach identifies how technological differences affect absolute advantage, it is silent about the impact of productivity on comparative advantage. Harrigan (1997) augments equation (1) with a technological parameter $\theta$, which represents technological differences at the industry level. This parameter introduces technology in a Hicksneutral manner implying that with the same amount of inputs, industry $i$ in country $c$ at year $t$ is $\theta$ times more productive than a reference point. ${ }^{1}$ Following the standard neoclassical approach, we construct a Relative Total Factor Productivity (RTFP) index to account for technological differences.

The augmentation of (1) with a technological parameter $\theta$ leads to the following revenue function:

$$
Y=r(\Theta P, V)
$$

where $\Theta=\operatorname{dia}\left\{\theta_{1}, . ., \theta_{I}\right\}$ is a diagonal matrix of Hicks-neutral technological parameters of industries $i$....I. The differentiation of (2) with respect to $\theta_{i}$ establishes the elasticity of industry i's output with respect to technical efficiency:

$$
\tilde{x}\left(\theta p_{i}, V\right)=\frac{\partial r\left(\theta_{i} p_{i}, V\right)}{\partial \theta_{i}}
$$

Following Woodland (1982) and Kohli (1991) the revenue function takes a second order translog form as follows:

\footnotetext{
${ }^{1}$ In the construction of the technological parameter, we show that the reference point is an arithmetic mean of all observations included in the sample.

${ }^{2}$ According to Trefler's (1995) methodology in modelling technological differences, the revenue function is expressed as: $Y=\Theta r(P, V)$. The interpretation of this suggests that a positive technological shock increases output in all industries leaving unaffected industry i's comparative advantage.
} 


$$
\begin{aligned}
\ln r(\theta p, V)= & \beta_{00}+\sum_{i} \beta_{0 i} \ln \theta_{i} p_{i}+\frac{1}{2} \sum_{i} \sum_{k} \beta_{i, k} \ln \theta_{i} p_{i} \ln \theta_{k} p_{k}+\sum_{j} \gamma_{0 j} \ln V_{j}+ \\
& \frac{1}{2} \sum_{j} \sum_{m} \gamma_{j, m} \ln V_{j} \ln V_{m}+\sum_{i} \sum_{j} \delta_{i, j} \ln \theta_{i} p_{i} \ln V_{j}
\end{aligned}
$$

where the summations in $i$ and $k$ refer to industries running from 1 to $I$ and summations in $j$ and $m$ refer to factor endowments running from $j$ to $J$. Assuming symmetry in cross effects we can impose: $\beta_{i, k}=\beta_{k, i}$ and $\gamma_{j, m}=\gamma_{m, j}$. Similarly, the linear homogeneity restriction in the revenue function yields:

$$
\sum_{i} \beta_{0 i}=1, \sum_{j} \gamma_{0 j}=1, \sum_{i} \beta_{i, k}=0, \sum_{j} \gamma_{j, m}=0, \sum_{j} \delta_{i, j}=0
$$

Differentiating (4) with respect to $p_{i}$ (after adding country subscripts). we obtain the share of industry $i$ 's to GDP: ${ }^{3}$

$$
s_{i, c, t}=\beta_{0, i}+\sum_{i=1} \beta_{i, k} \ln \left(\frac{p_{i, c, t}}{p_{1, c, t}}\right)+\sum_{i=1}^{I=4} \beta_{i, k} \ln \left(\frac{\theta_{i, c, t}}{\theta_{1, c, t}}\right)+\sum_{j=1}^{J=10} \delta_{j} \ln V_{j, c, t}
$$

The interpretation of (5) is that industry i's output share (s) to country $c^{\prime}$ s GDP is a function of technology $(\theta)$, prices of final goods $(p)$ and factor endowments $(V) .{ }^{4}$ A change in any of the right-hand side variables in equation (5) leads to adjustments until a new equilibrium is restored, satisfying producer and consumer optimisation as well as clearance in goods and factors markets.

Equation (5) can be simplified by assuming that differences in relative prices can be replaced by a set of time dummies. Finally, to obtain our empirical model, we augment equation (5) with a well-behaved error term:

\footnotetext{
${ }^{3}$ Cadot et al. (2007) present in detail how the homogeneity restrictions provided above can be reformulated in order to express all the determinants of specialisation relative to a reference value.

${ }^{4}$ The assumption of equal cross-country prices due to free trade and common crosscountry technology leads to a reduced version of (5) where both the second and third terms are replaced by a set of time and country dummies. This transformation is used for testing the original $\mathrm{H}-\mathrm{O}$ model with factor supplies as the sole determinant of specialisation (Redding and Vera-Martin, 2006).
} 


$$
s_{i, c, t}=\beta_{0, i}+\sum_{i=1}^{I=4} \beta_{i, k} \ln \left(\frac{\theta_{i, c, t}}{\theta_{1, c, t}}\right)+\sum_{j=1}^{J=10} \delta_{j} \ln V_{j, c, t}+\sum_{t=2}^{T=20} \gamma D_{t}+u_{i, c, t}
$$

where $D$ refers to time fixed effects and $u$ is a residual with zero mean and constant variance.

Intuitively, equation (6) presents an equilibrium relationship in which output shares in each sector depend on nation-wide factor endowments and industry specific productivity. Own industry productivity will be positively related to the output share of that particular industry, ceteris paribus. Cross-industry productivity picks up externalities effects. Theoretically, these are expected to be symmetrical, as discussed in Harrigan (1997), but the strength of the relationship can only be assessed empirically as it will depend on how technological improvements in one sector spread across the economy and are implemented in other sectors.

As discussed in the introduction, the set of factor endowments used in our analysis includes tangible and intangible assets. Increasing factor endowments, both tangible and intangible, should increase the output shares of those sectors that intensively use a particular factor. For example, we expect R\&D and skilled labour to positively affect output shares in Manufacturing as a large proportion of $R \& D$ investment is undertaken within this sector. There is now unanimous consent in classifying ICT as a General Purpose Technology (GPT) given its widespread diffusion and adoption. Although positive returns from ICT have been enjoyed in most industries, the Service sector has particularly benefited from the new technology (Inklaar et al., 2008) and therefore we expect a positive impact of ICT on the de-industrialisation process. Endowments of capital assets and energy are expected to increase the shares of the Manufacturing industry.

Our methodological approach encompasses many of the international trade conventions. For example, new economic growth theories pay special attention to input accumulation and production inefficiencies in understanding cross-country output patterns. ${ }^{5}$ Additionally, the industrial organisation literature builds upon the Schumpeterian notion linking firm survival and growth to efficiency level (Jovanovic, 1982). This idea of creative destruction has contributed largely to our understanding of how industries evolve over time. Our study endeavours to address similar questions with those documented in the literature of empirical growth and industrial organisation. However, while the latter depends on a partial equilibrium framework, our approach relies on a general equilibrium

\footnotetext{
${ }^{5}$ Temple (1999) offers an overview of the main approaches used as well as findings of the new growth theory.
} 
setting and the coefficients in equation (6) represent Rybczynski effects. These imply that the accumulation of a specific factor increases the share of the sector that uses intensively that factor while decreases output shares of the other sectors.

\section{Data and Measurement Issues}

\subsection{Coverage of Countries and Industries}

The empirical implementation of equation (6) requires both industry and country level data. Our sample includes seven European countries, Austria, Denmark, Finland, Germany, Italy, Netherlands and the UK, observed over the 1981-2003 period.

Table 1 - Industries' Value Added Shares in 1981 and 2003

\begin{tabular}{|c|c|c|c|c|c|c|c|c|}
\hline & & AUT & DNK & FIN & GER & ITA & NLD & UK \\
\hline & \multicolumn{8}{|c|}{ PANEL A } \\
\hline \multirow{2}{*}{ Agriculture } & 1981 & 5.28 & 5.21 & 8.94 & 2.34 & 5.62 & 4.37 & 2.32 \\
\hline & 2003 & 1.95 & 1.98 & 3.18 & 0.98 & 2.53 & 2.35 & 1.00 \\
\hline \multirow{2}{*}{ Manufacturing } & 1981 & 23.24 & 18.14 & 26.65 & 28.73 & 27.81 & 17.29 & 24.81 \\
\hline & 2003 & 19.45 & 15.04 & 24.14 & 22.37 & 19.04 & 14.15 & 14.28 \\
\hline \multirow{2}{*}{ Financial Intermediation } & 1981 & 5.04 & 4.56 & 2.45 & 4.34 & 5.18 & 5.13 & 5.32 \\
\hline & 2003 & 5.23 & 5.37 & 2.21 & 4.73 & 4.79 & 7.26 & 7.11 \\
\hline \multirow{2}{*}{ Business Services } & 1981 & 3.05 & 4.57 & 3.02 & 6.35 & 4.51 & 6.34 & 5.13 \\
\hline & 2003 & 8.69 & 8.17 & 6.87 & 12.58 & 10.91 & 12.09 & 13.84 \\
\hline & \multicolumn{8}{|c|}{ PANEL B } \\
\hline \multirow{2}{*}{ Mining \& Quarrying } & 1981 & 1.53 & 0.47 & 0.46 & 1.48 & 0.83 & 7.35 & 8.83 \\
\hline & 2003 & 0.42 & 2.52 & 0.29 & 0.20 & 0.39 & 2.46 & 2.15 \\
\hline \multirow{2}{*}{ Electricity, Gas, Water } & 1981 & 2.98 & 1.59 & 3.43 & 2.52 & 0.92 & 2.63 & 3.24 \\
\hline & 2003 & 2.37 & 2.10 & 2.28 & 1.91 & 2.01 & 1.70 & 1.65 \\
\hline \multirow{2}{*}{ Construction } & 1981 & 8.06 & 5.49 & 7.26 & 7.35 & 7.55 & 6.30 & 5.97 \\
\hline & 2003 & 7.75 & 5.31 & 5.28 & 4.39 & 5.63 & 5.55 & 6.04 \\
\hline \multirow{2}{*}{ Wholesale \& Retail } & 1981 & 13.93 & 13.50 & 11.35 & 10.23 & 14.01 & 11.00 & 10.01 \\
\hline & 2003 & 12.94 & 12.16 & 10.43 & 10.43 & 12.07 & 13.28 & 12.05 \\
\hline \multirow{2}{*}{ Hotels \& Restaurants } & 1981 & 4.12 & 1.47 & 1.55 & 1.39 & 2.79 & 1.58 & 2.18 \\
\hline & 2003 & 4.57 & 1.47 & 1.42 & 1.59 & 3.67 & 1.92 & 3.06 \\
\hline \multirow{2}{*}{$\begin{array}{l}\text { Transport, Storage \& } \\
\text { Communication }\end{array}$} & 1981 & 7.71 & 6.61 & 8.88 & 6.22 & 6.78 & 6.65 & 7.64 \\
\hline & 2003 & 7.33 & 8.35 & 11.03 & 5.74 & 7.64 & 7.44 & 7.64 \\
\hline \multirow{2}{*}{ Real Estate } & 1981 & 7.87 & 14.42 & 10.25 & 13.92 & 10.21 & 11.27 & 8.08 \\
\hline & 2003 & 17.07 & 18.14 & 17.76 & 24.52 & 21.75 & 19.36 & 21.72 \\
\hline \multirow{2}{*}{ Other Services } & 1981 & 17.19 & 23.97 & 15.76 & 15.13 & 13.79 & 20.09 & 16.46 \\
\hline & 2003 & 12.24 & 19.40 & 15.13 & 10.57 & 9.56 & 12.44 & 9.48 \\
\hline
\end{tabular}

Source: EUKLEMS (2007).

Our empirical analysis focuses on 4 major sectors, namely Agriculture, Manufacturing, Financial Intermediation and Business Services. These 
sectors have experienced the largest changes in their output shares over time compared to the rest of the economy and therefore they can provide important insights as to what forces have affected countries' specialisation. Table 1 shows, for each of the seven countries included in the analysis, the value added shares for the 4 sectors in our study (Panel A) and for the rest of the economy (Panel B). As expected, between 1981 and 2003 all countries experience a decline of the Agricultural and Manufacturing sectors. Finland and Germany have the highest manufacturing shares compared to the other 5 countries. The UK has been particularly fast in the process of de-industrialisation compared to the other countries, as demonstrated by the largest decrease in Manufacturing shares between 1981 and 2003. This has been accompanied by a large increase in the Financial Intermediation industry, which has been documented in the existing literature (Inklaar and Koetter, 2008). On the other hand, Financial Intermediation has only had a marginal increase in Austria (5.04 in 1981 and 5.23 in 2003) while its shares have declined slightly in Finland. The increase in the value added shares of Business Services is more pronounced in all countries.

To get more insights into changes in the industry structure in the 7 countries we plot the movements in the value added shares over time in Figures 1-4. Consistent with prior expectations, the value added shares in Agriculture have been characterised by a declining trend throughout the period.

Figure 1-Agriculture: Trends in Value Added Shares

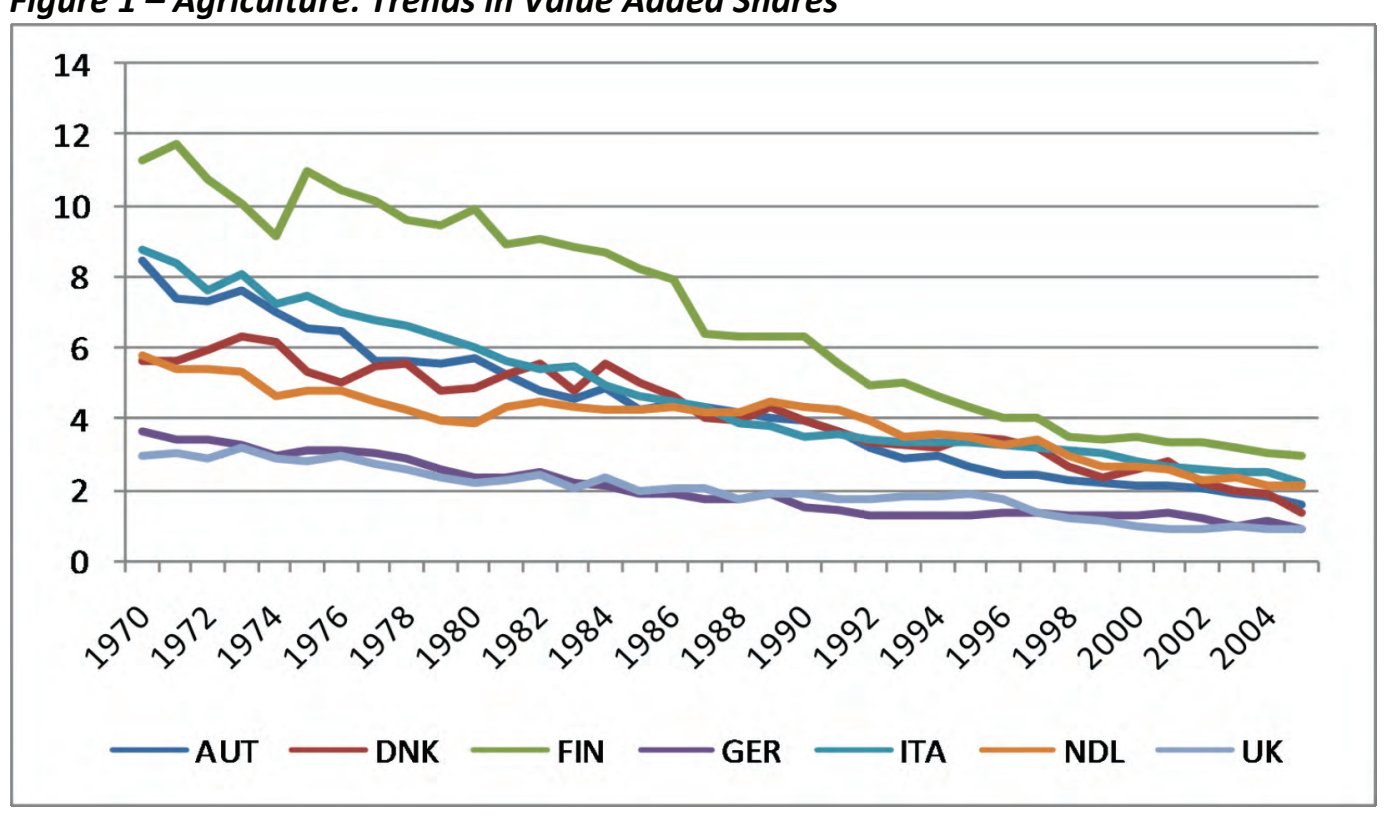


Figure 2 - Manufacturing: Trends in Value Added Shares

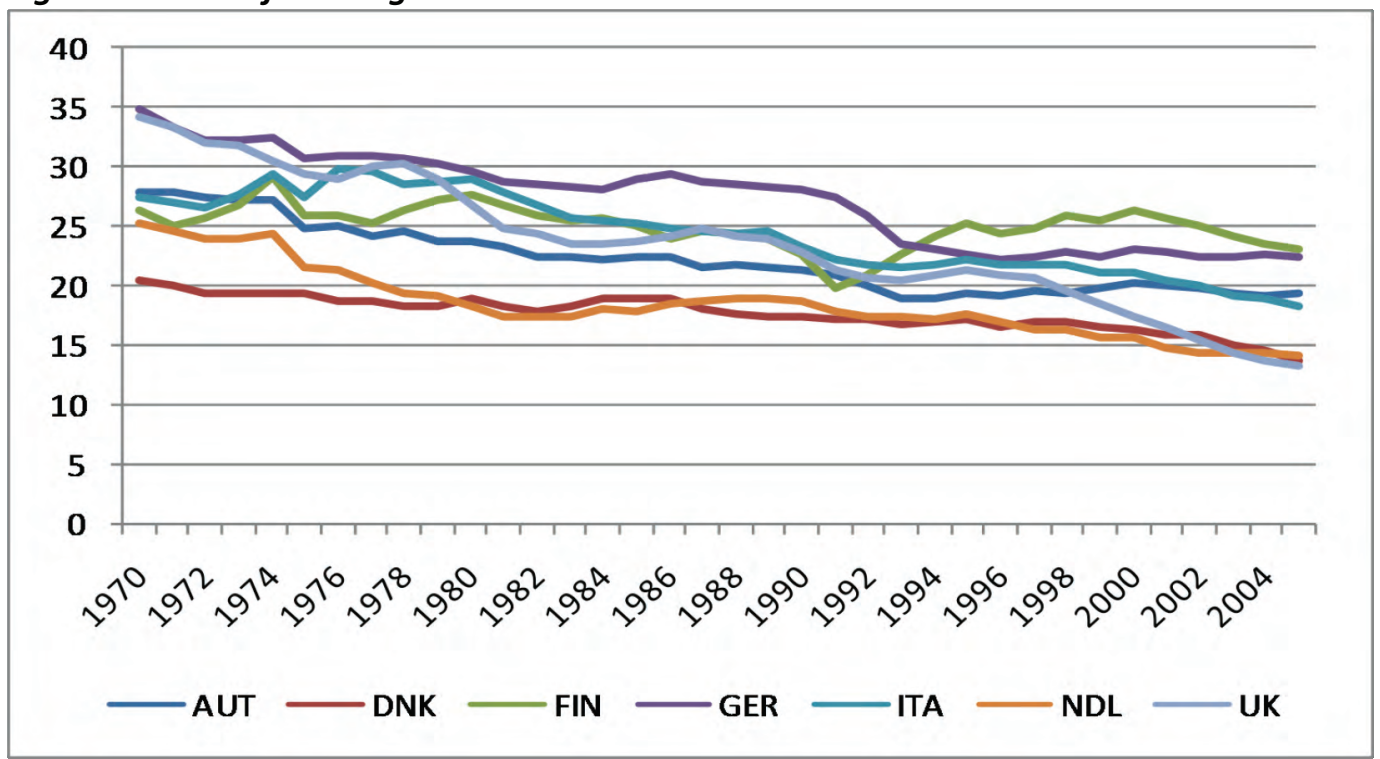

In Manufacturing, most countries experience a decline in value added shares throughout the period too. However, Finland breaks the declining trend and Manufacturing shares start increasing in the early 1990s and remain at relatively high levels throughout the 1990s and the first years of the new millennium. This coincides with a period of intensive investments in R\&D and ICT and the development of high-tech companies like Nokia (Jalava and Pohjola, 2007).

Figure 3 - Financial Intermediation: Trends in Value Added Shares

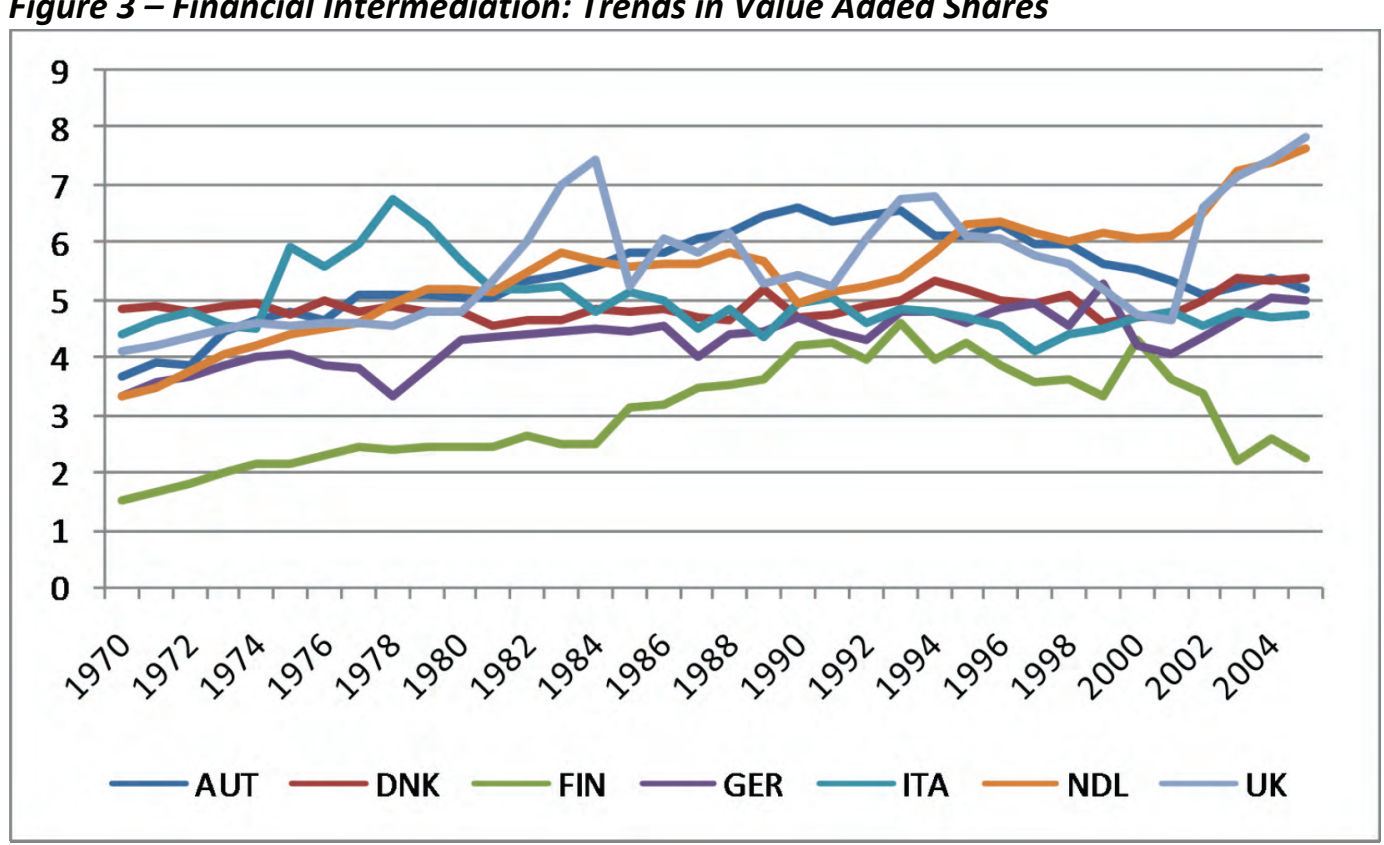


The Financial Intermediation sector, depicted in Figure 3, shows more volatility over time, particularly in the UK and in Italy. Austria and the UK see their shares increasing rapidly in the first 10 years of the sample but only the UK maintains the high shares in the 1990s. The performance of the Financial Intermediation sector in this country is only matched by the Netherlands. In Finland, on the other hand, shares decline rapidly in the last 5 years. In Business Services all countries experience a similar increasing trend.

Figure 4-Business Services: Trends in Value Added Shares

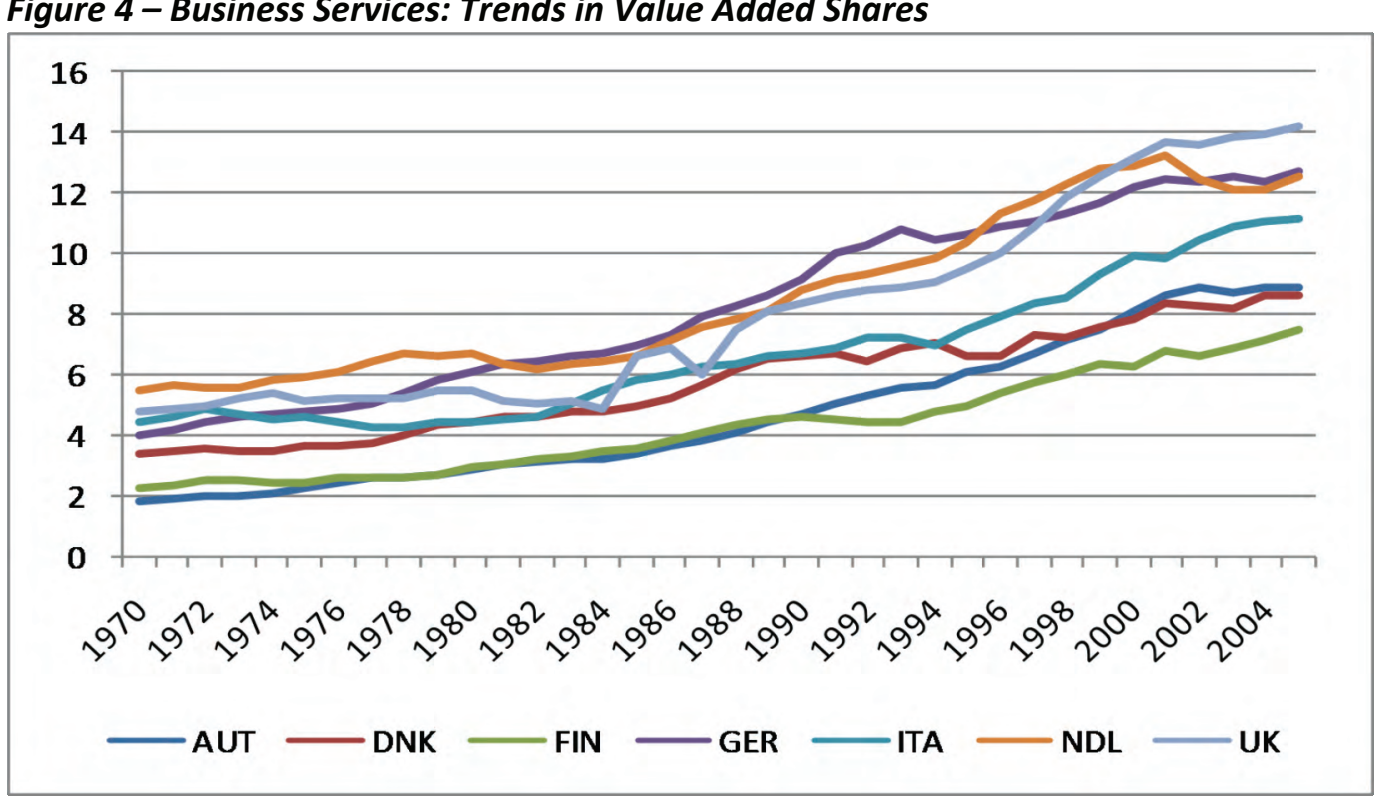

\subsection{National Factor Supplies}

The group of economy-wide factor supplies consists of tangible assets (unskilled labour, capital, energy and land) and intangible assets (R\&D capital and skilled labour). Data on labour is provided by the Barro-Lee (2001) data set, which classifies the labour force into six categories using information on educational attainment and gender. Specifically information is provided on (i) the share of the population with primary education, (ii) the share of the population with secondary education and (iii) the share of the population with tertiary education. Information on skills allows the evaluation of the impact of human capital on international specialisation. Table 2 shows the shares of the population for the total across gender groups at the beginning and at the end of our sample. Over the past 30 years the supply of skilled labour has increased dramatically in all countries, as the result of an increasing number of students entering higher education in most developed economies (Autor et al., 1998). These trends in skills endowment can have an important 
impact on specialisation. Average trends in labour endowments are very similar across countries, particularly for the primary and tertiary skills proportions. The proportion of the population with secondary education is characterised by some cross country variation; for example we observe decreasing shares in Austria and in Italy, no changes in the Netherlands and increasing shares everywhere else. These trends mirror differences in the qualification systems, particularly in the intermediate skill category. ${ }^{6}$

Table 2 - Educational Characteristics of the Labour Force. Shares in Total Population

\begin{tabular}{|c|c|c|c|c|c|c|c|c|c|c|c|c|c|c|}
\hline \multirow[b]{2}{*}{ year } & \multicolumn{2}{|c|}{ AUT } & \multicolumn{2}{|c|}{ DNK } & \multicolumn{2}{|c|}{ FIN } & \multicolumn{2}{|c|}{ GER } & \multicolumn{2}{|c|}{ ITA } & \multicolumn{2}{|c|}{ NLD } & \multicolumn{2}{|c|}{ UK } \\
\hline & 1981 & 2003 & 1981 & 2003 & 1981 & 2003 & 1981 & 2003 & 1981 & 2003 & 1981 & 2003 & 1981 & 2003 \\
\hline Primary & 34.1 & 25.9 & 37.9 & 29.5 & 51.5 & 27.0 & 38.9 & 24.2 & 57.8 & 44.1 & 42.4 & 28.9 & 79.4 & 64.5 \\
\hline Secondary & 62.0 & 54.8 & 44.2 & 46.1 & 36.0 & 44.9 & 53.9 & 54.3 & 36.4 & 35.3 & 45.4 & 45.4 & 15.5 & 17.2 \\
\hline Tertiary & 3.9 & 19.3 & 18.0 & 24.5 & 12.5 & 28.0 & 7.2 & 21.5 & 5.7 & 20.6 & 12.2 & 25.7 & 5.1 & 18.3 \\
\hline
\end{tabular}

Source: Barro and Lee (2001). Population is defined as total population aged 15 and over.

Information on capital stock is obtained from the EU-KLEMS data base. ${ }^{7}$ Capital stock is measured by capital service flows and is constructed using information on investment at current and constant prices from six asset types: computers, communication equipment, software (ICT capital), and transport equipment, other non-ICT machinery and equipment, nonresidential (non-ICT capital). Data on R\&D expenditure is Gross Domestic Expenditure on R\&D (GERD) from the OECD STAN indicators. R\&D expenditure is converted into a stock measure using a perpetual inventory method, assuming a pre-sample growth rate of $5 \%$ and a depreciation rate of $15 \%$ (Hall, 1990). Finally, the International Energy Agency is our source for energy data. This refers to various energy factors converted into oil equivalent. ${ }^{8}$ Additional information on factor supplies data are discussed in the Appendix.

Table 3 summarises the main trends characterising the supply of tangible and intangible capital in the $7 \mathrm{EU}$ countries included in our analysis. For each asset we present the average intensity over the whole

\footnotetext{
${ }^{6}$ The distinction between primary, secondary and tertiary education has its limitation as it hides differences in the education sector in the 7 countries ( $\mathrm{O}^{\prime}$ Mahony and Timmer, 2009). However, data with more detail in terms of educational attainment is quite difficult to find for the 7 countries in our analysis.

${ }^{7}$ Reader can be referred to Timmer et al. (2007) for a more detailed description regarding the construction of ICT and non-ICT capital stock.

${ }^{8}$ In a previous version of the paper, we also included land, measured in hectares of either arable or agricultural land as reported from the Food and Agriculture Organisation of the United Nations (FAO Statistics Division). However, this variable was never statistically significant at conventional significance level therefore we eliminated it from the analysis. Given that quantity of land changes slightly over time, its effect is captured by country fixed effects.
} 
period and in two sub-periods, 1981-1989 and 1990-2003. Capital intensity, defined as the capital stock divided by the total number of employees, is quite heterogeneous across countries. The level of ICT capital intensity is of similar magnitude across the EU countries and it has increased in the last part of the sample period as all countries gradually adopted the new technology. More cross-country variation can be observed in R\&D intensity and in its changes over time. Next to the decrease in Germany, due to reunification, we can observe a sizeable increase in Finland, where R\&D intensity grew from $0.26 \%$ in the period $1981-1989$, to $0.64 \%$ between 1990 and 2003. With the exception of Italy and Germany, non-ICT capital intensity has increased in most countries but the levels are still particularly low in the UK.

Table 3 - Average Capital Intensity (in \%)

\begin{tabular}{lllllllll}
\hline \hline \multirow{3}{*}{ R\&D intensity } & & AUT & DNK & FIN & GER & ITA & NLD & UK \\
& $1981-2003$ & 0.37 & 0.39 & 0.49 & 1.2 & 0.35 & 0.55 & 0.56 \\
& $1981-1989$ & 0.26 & 0.24 & 0.26 & 1.81 & 0.29 & 0.48 & 0.50 \\
& $1990-2003$ & 0.45 & 0.48 & 0.64 & 0.8 & 0.38 & 0.59 & 0.59 \\
\hline \multirow{3}{*}{ ICT intensity } & $1981-2003$ & 0.38 & 0.41 & 0.35 & 0.54 & 0.46 & 0.44 & 0.45 \\
& $1981-1989$ & 0.15 & 0.09 & 0.12 & 0.53 & 0.34 & 0.17 & 0.15 \\
& $1990-2003$ & 0.53 & 0.61 & 0.5 & 0.55 & 0.55 & 0.61 & 0.64 \\
\hline \multirow{3}{*}{ Non ICT intensity } & $1981-2003$ & 16.33 & 17.06 & 13.3 & 28.29 & 16.21 & 15.28 & 9.88 \\
& $1981-1989$ & 13.9 & 16.28 & 11.16 & 41.95 & 19.92 & 13.84 & 9.62 \\
& $1990-2003$ & 17.9 & 17.56 & 14.68 & 19.5 & 13.83 & 16.2 & 10.05 \\
\hline
\end{tabular}

Notes: Capital intensity is defined as capital stock divided by the total number of employees. Data on R\&D is from the OECD Stan indicators. The rest of the data is from EUKLEMS (2007).

\subsection{Measurement of Relative Total Factor Productivity (RTFP)}

Our measure of Hicks-neutral technology is Total Factor Productivity index. The construction of this index follows the methodology suggested by Caves et al. (1982), van Ark and Pilat (1993) and Harrigan (1999). The derivation of this index is based on the assumption that value added is produced by two heterogeneous inputs, labour $(L)$ and capital $(K)$ whose structure is explained in the following sub-sections. The methodology adopted in this analysis accounts for differences in quantity and quality of the inputs in the different countries. The current measure of TFP is based on the standard neoclassical assumptions of perfect competition and constant returns to scale. TFP in each country is expressed relative to a hypothetical frontier or reference country. The latter is the average level of TFP in the 7 countries in each industry. For each industry $i$ of country $c$ at year $t$ the production function is written as: 


$$
Y_{c, i, t}=f\left(L_{c, i, t}, K_{c, i, t}\right)
$$

Assuming a Cobb-Douglas production technology, we can re-write equation (7.0) as follows:

$$
Y_{c, i, t}=A_{c, i, t} L_{c, i, t}^{\alpha_{L}} K_{c, i, t}^{1-\alpha_{L}}
$$

The technology parameter $A$ is measured by an index of total factor productivity. We define the production function of the reference country as:

$$
\bar{Y}_{i, t}=A_{i, t} \bar{L}_{i, t}^{\alpha_{L}} \bar{K}_{i, t}^{1-\alpha_{L}}
$$

The bar over a variable indicates the geometric average of all observations in an individual industry $i$ for year $t$. Therefore, the logarithmic expression of RTFP (relative total factor productivity) is given by:

$$
\begin{aligned}
\log R T F P_{c, i, t} & =\left(\log Y_{c, i, t}-\log \bar{Y}_{i, t}\right)-\bar{\sigma}_{c, i, t}^{L}\left(\log L_{c, i, t}-\log \bar{L}_{i, t}\right) \\
& -\left(1-\bar{\sigma}_{c, i, t}^{L}\right)\left(\log K_{c, i, t}-\log \bar{K}_{i, t}\right)
\end{aligned}
$$

The labour share $\alpha$ is measured as the ratio of labour compensation to value added. The weighted variable $\bar{\sigma}_{i, t}^{L}=\left(\alpha_{i, t}^{L}+\bar{\alpha}_{i, t}^{L}\right) / 2$ is the labour share's arithmetic mean of all observations in industry $i$ at year $t$.

The EU-KLEMS database from the Groningen Growth and Development Centre (GGDC) is the main data provider for the construction of TFP. To obtain a meaningful measure of RTFP, we convert value added, labour and capital compensation and investment in capital assets into US Dollars using the GDP purchasing power parity (PPP) exchange rates reported by the World Bank Development Indicators International Comparison Project (ICP). ${ }^{9}$ Finally, we express all values in 1995 constant prices using the industry price deflators of the EU-KLEMS data base.

Labour input in equation (8) accounts for heterogeneous labour by aggregating three types of workers using a translog index:

$$
L_{c, i, t}=\sum_{1}^{3} \bar{v}_{c, i, t}^{\zeta} \bar{l}_{c, i, t}^{\zeta}
$$

\footnotetext{
${ }^{9}$ There are limitations with the use of a GDP PPP-exchange rate conversion method if one takes into account that prices differ across sectors in the economy. Provided that PPPexchange rates for a disaggregate industry level are not available for a long time series, we believe that the method used is the best alternative.
} 
The three types of labour are identified according to their educational attainment, so we distinguish low-skilled labour (i.e. degree from primary or lower education), medium skilled (i.e. degree from secondary education), and high skilled labour (degree from University or postgraduate qualifications). ${ }^{10}$ Share $v$ is a weighted measure of the share of each labour type $\zeta$ in total labour compensation defined as: $\bar{v}_{c, i, t}^{\zeta}=$ $\left(\alpha_{i, t}^{\zeta}+\bar{\alpha}_{i, t}^{\zeta}\right) / 2$, where the weight is given by the arithmetic mean of all observations in industry $i$ at year $t$. Lower case $l$ denotes the total number of hours worked for each individual labour type.

Similarly to the labour input, we use a translog index to calculate the measure of capital input in equation (8):

$$
K_{c, i, t}=\sum_{1}^{2} \bar{v}_{c, i, t}^{\lambda} \bar{S}_{c, i, t}^{\lambda}
$$

We distinguish two broad types of capital assets, non-ICT and ICT capital assets. The former group aggregates investment in transport equipment, machinery, residential and non-residential construction while the latter includes investment in IT systems, computing and software. The weighted share of each capital stock asset in total capital compensation is defined as: $\bar{v}_{c, i, t}^{\lambda}=\left(\alpha_{i, t}^{\lambda}+\bar{\alpha}_{i, t}^{\lambda}\right) / 2$. Variable $S$ stands for the stock measure of each asset as calculated from the perpetual inventory method:

$$
S_{i, t}^{\lambda}=\left(1-\delta^{\lambda}\right) S_{i, t-1}^{\lambda}+I_{i, t-1}^{\lambda}
$$

Symbol $\delta$ indicates the degree of physical depreciation for capital asset $\lambda$ and $I$ is real investment in this asset. The formula used to initiate the series is given by:

$$
S_{i, 0}^{\lambda}=I_{0}^{\lambda} /\left(\delta^{\lambda}+g_{i}^{\lambda}\right)
$$

where $g^{\lambda}$ is the average growth rate of investment in asset $\lambda$ over the whole sample. For the pattern of physical depreciation rate, we follow the methodology of geometric depreciation suggested by Jorgenson et al. (2005). Accordingly, the depreciation rate for ICT assets is common for all

\footnotetext{
${ }^{10}$ In the construction of relative TFP we use the skills data from EU-KLEMS (O'Mahony and Timmer, 2009). This data set provides information on the total number of hours worked by low, intermediate and highly skilled workers and it is therefore more suitable than the Barro-Lee (2001) classification for productivity measurement. The skill data from the Barro-Lee (2001) refers to the total population and it is therefore more suitable as a measure of national endowment.
} 
industries and set equal to 0.215 , which is the average value of the depreciation rate of computers (0.315) and software (0.011). For non-ICT capital assets, the depreciation rate varies both across assets and across industries, indicatively we mention here the rates of depreciation for the total economy, which are 0.18 for transport equipment, 0.126 for machinery, 0.011 for residential construction and 0.031 for non-residential construction. ${ }^{11}$

\section{Methodology}

Our empirical analysis is based on the estimation of equation (6) by pooling data for the 7 countries over the period 1981-2003. We estimate equation (6) separately for each of the four sectors using a Fixed Effect estimator to control for unobserved country heterogeneity. As already mentioned, equation (6) represents a long-term equilibrium relationship. Nonetheless, this is only a theoretical consideration and we need to check the empirical validity of this argument by testing our variables for stationarity and cointegration. ${ }^{12}$ Figures 1-4 clearly suggest that the value added shares are non-stationary and, as for the factors supply, the existing empirical evidence has already discussed the possibility of nonstationarity of capital assets, particularly ICT capital (O'Mahony and Vecchi, 2005). Results of the stationarity tests, reported in Appendix Table A.2, show that for most of our series the null of non-stationarity could not be rejected at the 5\% significance level. Cointegration tests are presented on the last row of Table 4. For all four equations the null of no cointegration can always be rejected suggesting that equation (6) captures a long-term relationship between value added shares, factor endowments and productivity.

Another underlying assumption of the model specified in (6) is that factors of production can freely move across sectors. However, changes in industry structure are likely to be characterised by time hysteresis. In that case, equation (6) represents only the static effect between factor endowments and value added shares. To capture the dynamics of specialisation we allow for slow adjustment to long-term equilibrium as follows:

\footnotetext{
${ }^{11}$ The reader can find the full list of the different depreciation rates across industries in the appendix of the EU-KLEMS manual (2007).

${ }^{12}$ Sector shares, defined as the shares of industry value added to total value added for the whole economy, are restricted to be between zero and one implying that this variable cannot follow a random walk. However, in a finite sample of 23 years as used in the current study, sectoral value added shares may act as though they have a unit root.
} 


$$
s_{i, c, t}=\phi_{i} s_{i, c, t-1}+\beta_{0, i}+\sum_{i=1}^{I=4} \beta_{i, k} \ln \left(\frac{\theta_{i, c, t}}{\theta_{1, c, t}}\right)+\sum_{j=1}^{J=10} \delta_{j} \ln V_{j, c, t}+\sum_{t=2}^{T=20} \gamma D_{t}+u_{i, c, t}
$$

Where $\left(1-\phi_{i}\right)$ is the sector specific speed of adjustment to the long-run equilibrium. Long run parameters are easily derived by dividing each coefficient estimate by $\left(1-\phi_{i}\right)$.

Finally, industry shares might cause feedback effects to the contemporaneous values of relative TFP raising the issue of endogeneity. Similarly, endogeneity can result from the presence of the lagged dependent variable on the right hand side of equation (10). Since our empirical model is derived from a dual translog revenue function that is valid for every point in the sample we do not need to address explicitly the issue of a possible endogeneity between sectoral shares and factor endowments (Redding and Martin, 2006; Harrigan, 2001). Results based on an instrumental variable estimator are discussed in detail in the following section.

\section{Results and Discussion}

The results of the estimation of the static model (equation 6) are presented in Table 4. For each equation, the dependent variable is the percentage share of that sector's value added over the value added for the whole economy as shown in Figures 1-4. Endowments of labour by skills and gender are derived by multiplying the Barro-Lee (2001) shares with the working age population (aged 15 to 65). We then construct a measure of skilled labour by aggregating the total number of people with secondary and tertiary education (skilled). The decision to classify both groups in the 'skilled' category was dictated by two main reasons. Firstly, from a statistical point of view, the correlation between the two groups is very high (0.89) and this makes it impossible to disentangle the separate influences of the two variables. Secondly, education systems vary greatly across countries, particularly in the provision of intermediate education (Mason et al., 2010). Hence, the aggregation of the two components provides a better evaluation of the skill endowment in each country. The total number of people with primary education is also included in our specification to account for the total labour endowment. ${ }^{13}$ In order to address the issue of endogeneity of relative TFP we estimate equation (6)

\footnotetext{
${ }^{13}$ We initially included all skill and gender information in our analysis. However, the high correlation among the different components produced highly misleading results. This was also noted by one of our anonymous referee who suggested dropping the gender classification.
} 
by a Two Stage Least Square estimator (2SLS), using higher order lags of the endogenous variables as instruments. The validity of the instruments is tested at the bottom of Table 4 by the Kleibergen-Paap LM test and the Hansen J test.

Table 4 - Instrumental Variable Estimation: Static Model

\begin{tabular}{|c|c|c|c|c|}
\hline & Agriculture & Manufacturing & $\begin{array}{c}\text { Financial } \\
\text { Intermediation }\end{array}$ & $\begin{array}{l}\text { Business } \\
\text { Services }\end{array}$ \\
\hline \multirow{2}{*}{ TFP Agriculture } & -0.006 & $-2.569 * * *$ & $0.643 * *$ & -2.446 \\
\hline & $(0.372)$ & $(0.673)$ & $(0.320)$ & (2.094) \\
\hline \multirow{2}{*}{ TFP Manufacturing } & 0.352 & $8.746 * * *$ & $-0.978 * *$ & -2.226 \\
\hline & $(0.306)$ & $(1.003)$ & $(0.488)$ & (3.118) \\
\hline \multirow{2}{*}{ TFP Fin. Intermediation } & $-0.379 *$ & $1.304 * * *$ & $1.635^{* * *}$ & -4.084 \\
\hline & $(0.197)$ & $(0.476)$ & $(0.518)$ & (2.759) \\
\hline \multirow{2}{*}{ TFP Business Services } & -0.302 & $2.113 * * *$ & $-0.705^{*}$ & 9.749 \\
\hline & $(0.238)$ & $(0.595)$ & (0.394) & (6.438) \\
\hline \multirow{2}{*}{ ICT capital } & 0.310 & $-5.454 * * *$ & $1.215^{* * *}$ & -0.281 \\
\hline & $(0.259)$ & $(0.673)$ & $(0.441)$ & $(1.456)$ \\
\hline \multirow{2}{*}{ Non-ICT capital } & $2.590 * * *$ & $-14.442 * * *$ & $-2.104^{*}$ & $8.075^{*}$ \\
\hline & $(0.769)$ & $(2.335)$ & $(1.094)$ & (4.634) \\
\hline \multirow{2}{*}{ Low skill } & 0.020 & 1.285 & -1.131 & -3.161 \\
\hline & $(0.612)$ & $(2.082)$ & (1.057) & (4.609) \\
\hline \multirow{2}{*}{ High skill } & $-4.859 * * *$ & $4.000^{*}$ & -0.554 & $9.715^{*}$ \\
\hline & $(0.572)$ & $(2.297)$ & $(1.036)$ & $(5.501)$ \\
\hline \multirow{2}{*}{ R\&D capital } & $-3.686 * * *$ & $4.418 * * *$ & -0.496 & 0.328 \\
\hline & $(0.375)$ & (1.089) & $(0.555)$ & (3.096) \\
\hline \multirow{2}{*}{ Energy } & $0.677^{* *}$ & $2.550 * * *$ & $-1.611 * * *$ & 2.119 \\
\hline & $(0.295)$ & $(0.729)$ & $(0.354)$ & (2.055) \\
\hline Observations & 147 & 133 & 147 & 140 \\
\hline R-squared & 0.949 & 0.919 & 0.391 & 0.824 \\
\hline \multirow{2}{*}{$\begin{array}{l}\text { Kleibergen-Paap } \\
\text { (P value) }\end{array}$} & 21.60 & 28.22 & 29.32 & 2.591 \\
\hline & $(0.000)$ & $(0.000)$ & $(0.000)$ & $(0.274)$ \\
\hline \multirow{2}{*}{$\begin{array}{l}\text { Hansen J } \\
\text { (P value) }\end{array}$} & 0.385 & 4.705 & 2.064 & 0.0759 \\
\hline & $(0.535)$ & $(0.100)$ & $(0.151)$ & $(0.783)$ \\
\hline \multirow[t]{2}{*}{ Cointegration test } & -0.278 & -0.064 & -1.204 & -0.410 \\
\hline & $(0.391)$ & $(0.474)$ & (0.114) & $(0.341)$ \\
\hline
\end{tabular}

Notes: ${ }^{* * *}=$ significant at $1 \%,{ }^{* *}=$ significant at $5 \%,{ }^{*}=$ significant at $10 \%$. Country fixed effects are included in all specifications. Heteroskedasticityrobust standard errors in brackets. The Kleibergen-Paap LM statistic is the heteroskedasticity robust test of underidentification. The null hypothesis is that the equation is underidentified. The Hansen J test is the appropriate test of overidentifying restrictions in the presence of heteroskedasticity. The null hypothesis is that all instruments are valid. The cointegration test is the Im et al. (2002) test for panel unit roots on the residuals the cointegrating relationship (equation 6).

Theoretical predictions require symmetry in the cross-sector technology effects and positive within sector coefficients. In our study, we do not 
impose the symmetry condition, leaving the analysis to determine the strength of the cross-sector technology effects. Consistent with the theory, own industry technology effects are positive and significant in all sectors under investigation. Such effects are particularly large in Manufacturing, where a $10 \%$ improvement in relative TFP increases output shares by $0.87 \%$. This emphasises the importance of productivity improvements and innovations in affecting the value added shares of this sector. Own TFP is also positive and statistically significant in the Financial Intermediation sector, while in Business Services the coefficient is positive but not statistically significant at conventional levels. The only result not consistent with the theory is in Agriculture where we do not find any role for productivity improvements. Cross-industry effects are in many cases negative, supporting the Ricardian notion of comparative advantage such that an increase in relative productivity of one sector increases its output share while shrinking the output share of the rival sector. However, the statistical robustness of this result is not always strong; for example, productivity improvements in Financial Intermediation drive resources away from Business Services but interestingly they contribute to a larger Manufacturing sector. Similar patterns are documented in the existing evidence (Harrigan, 1997) and testify that productivity spillovers across industries are more complex than those predicted by the theory. In our case, they suggest the presence of complementarity between productivity improvements in Business Services and the shares of Manufacturing.

Turning to the impact of factor endowments, the coefficient estimates reveal not only that there is great cross-industry variation but also that accounting for capital heterogeneity and intangible assets improves our understanding of the patterns of specialisation. For example, endowments of ICT capital have a positive and significant impact on the output shares of Financial Intermediation, while they have contributed to a decrease in the shares of Manufacturing to a significant extent. This result is consistent with recent evidence showing that ICT capital has played an important role in fostering productivity growth in Services (Triplett and Bosworth, 2004; van Ark et al, 2003; van Ark et al., 2008). Additionally, the negative impact of ICT capital on the shares of the Manufacturing sector can be explained by the increasing trends in outsourcing, which are likely to be driven by the greater availability of ICT assets. As for non-ICT capital, its abundance drives resources away from Manufacturing and Financial Intermediation while increasing output shares in Agriculture and Business services. The result for Manufacturing goes against our expectations, given the capital-intensive nature of this sector. However, we have to bear in mind that two sources of unaccounted heterogeneity might affect this result: heterogeneity in the capital stock across industries, which is neglected in our measure of (country level) capital endowment, and 
heterogeneity in the impact of capital on the shares of individual manufacturing industries. Negative capital coefficients are in fact found, for example, in some of the industries analysed in Harrigan (1997) and Cadot et al. (2007).

Results are more consistent with our expectations when considering intangible factor endowments. Our analysis shows that $R \& D$ capital stock positively affects Manufacturing value added shares while driving resources away from Agriculture. A 10\% increase in R\&D capital contributes to a sizeable $0.44 \%$ increase in Manufacturing production. Our analysis also shows that endowments of R\&D do not play any significant role in the Service industry, which is somehow inconsistent with existing evidence of positive returns of R\&D investment in this sector ( $\mathrm{O}^{\prime}$ Mahony and Vecchi, 2009). This could be a compositional effect, given that we use an aggregate R\&D measure, which does not discriminate between types of innovations. ${ }^{14}$

Next to R\&D, the endowment of skilled workers also affects the output shares of Manufacturing. These two intangible assets are often considered as complement so we expect them to play a similar role. Interestingly, the availability of skilled workers increases the shares of Business Services, revealing the increasing importance of skilled labour in the Service Sector, possibly linked to the fast adoption of ICT.

As already discussed in section 4, we allow for a time lag in the way resources are reallocated across different sectors within the economy by estimating the dynamic model as in equation (10). Results are presented in Table 5. The lagged dependent variable is positive and significant in all equations confirming the hypothesis of partial adjustment discussed in section 4. The sign and significance of the short run coefficient is consistent with the results in Table 4 . The speed of adjustment to the long run equilibrium is different across sectors, as one would expect. Adjustments are particularly fast in the Financial Intermediation sector where nearly $55 \%$ of the adjustment takes place within one year, reflecting largely the dynamism of this sector. On the other hand, we observe the slowest speed of adjustment in Business Services (32\%).

Although institutional factors are likely to be the main reasons behind the different dynamic changes, it is worth noting that the Business Services sector has many peculiarities that might prevent a rapid adjustment. For example, this sector includes many R\&D activities whose outcomes take time to be implemented and to affect output shares. Additionally, R\&D activities might be associated with some protectionism (patents, copyrights, etc.) that create barriers to entry in this industry. An

\footnotetext{
${ }^{14}$ For example, the Service Sector is likely to be a more intensive user of soft innovations of more intangible nature.
} 
in depth analysis of these issues is beyond the scope of the present paper but it is a possible avenue for future research.

Table 5 - Instrumental Variable Estimation: Dynamic Model

\begin{tabular}{|c|c|c|c|c|}
\hline & Agriculture & Manufacturing & $\begin{array}{c}\text { Financial } \\
\text { Intermediation }\end{array}$ & $\begin{array}{l}\text { Business } \\
\text { Services }\end{array}$ \\
\hline Lagged shares & $\begin{array}{c}0.598 * * * \\
(0.157)\end{array}$ & $\begin{array}{c}0.478 * * * \\
(0.071)\end{array}$ & $\begin{array}{c}0.447 * * \\
(0.203)\end{array}$ & $\begin{array}{c}0.685 * * * \\
(0.115)\end{array}$ \\
\hline TFP Agriculture & $\begin{array}{c}0.097 \\
(0.323)\end{array}$ & $\begin{array}{c}-1.574 * * * \\
(0.493)\end{array}$ & $\begin{array}{c}0.406 \\
(0.322)\end{array}$ & $\begin{array}{l}-0.086 \\
(0.270)\end{array}$ \\
\hline TFP Manufacturing & $\begin{array}{l}-0.019 \\
(0.253)\end{array}$ & $\begin{array}{c}4.964 * * * \\
(0.842)\end{array}$ & $\begin{array}{c}-0.986 * * \\
(0.460)\end{array}$ & $\begin{array}{c}0.037 \\
(0.345)\end{array}$ \\
\hline TFP Fin. Intermediation & $\begin{array}{l}-0.207 \\
(0.172)\end{array}$ & $\begin{array}{c}0.276 \\
(0.445)\end{array}$ & $\begin{array}{l}1.012^{*} \\
(0.576)\end{array}$ & $\begin{array}{c}-0.870 * * * \\
(0.240)\end{array}$ \\
\hline TFP Business Services & $\begin{array}{l}-0.084 \\
(0.209)\end{array}$ & $\begin{array}{c}1.377^{* * * *} \\
(0.511)\end{array}$ & $\begin{array}{l}-0.350 \\
(0.418)\end{array}$ & $\begin{array}{c}1.388 * * * \\
(0.430)\end{array}$ \\
\hline ICT capital & $\begin{array}{l}-0.141 \\
(0.206)\end{array}$ & $\begin{array}{c}-3.190 * * * \\
(0.611)\end{array}$ & $\begin{array}{c}1.087 * * * \\
(0.418)\end{array}$ & $\begin{array}{l}-0.325 \\
(0.347)\end{array}$ \\
\hline Non-ICT capital & $\begin{array}{c}1.159 \\
(0.727)\end{array}$ & $\begin{array}{c}-9.243^{* * *} \\
(1.615)\end{array}$ & $\begin{array}{l}-1.499 \\
(0.977)\end{array}$ & $\begin{array}{c}1.162 \\
(1.265)\end{array}$ \\
\hline R\&D capital & $\begin{array}{l}-1.226 \\
(0.756)\end{array}$ & $\begin{array}{c}1.731 * * \\
(0.744)\end{array}$ & $\begin{array}{l}-0.426 \\
(0.469)\end{array}$ & $\begin{array}{l}-0.698 \\
(0.554)\end{array}$ \\
\hline Low skill & $\begin{array}{c}0.087 \\
(0.595)\end{array}$ & $\begin{array}{l}-0.509 \\
(1.250)\end{array}$ & $\begin{array}{l}-0.688 \\
(1.000)\end{array}$ & $\begin{array}{c}0.054 \\
(0.771)\end{array}$ \\
\hline High skill & $\begin{array}{l}-1.494 \\
(1.067)\end{array}$ & $\begin{array}{c}2.728 * * \\
(1.267)\end{array}$ & $\begin{array}{l}-0.401 \\
(0.922)\end{array}$ & $\begin{array}{c}2.166 * * \\
(0.903)\end{array}$ \\
\hline Energy & $\begin{array}{c}0.358 \\
(0.310)\end{array}$ & $\begin{array}{c}1.570 * * * \\
(0.467)\end{array}$ & $\begin{array}{c}-1.217^{* * *} \\
(0.382)\end{array}$ & $\begin{array}{l}0.467^{*} \\
(0.280)\end{array}$ \\
\hline Observations & 147 & 147 & 147 & 140 \\
\hline R-squared & 0.967 & 0.961 & 0.507 & 0.983 \\
\hline $\begin{array}{l}\text { Kleibergen-Paap } \\
\text { (P value) }\end{array}$ & $\begin{array}{c}19.14 \\
(0.000)\end{array}$ & $\begin{array}{c}30.35 \\
(0.000)\end{array}$ & $\begin{array}{c}13.00 \\
(0.002)\end{array}$ & $\begin{array}{c}12.32 \\
(0.015)\end{array}$ \\
\hline $\begin{array}{l}\text { Hansen J } \\
\text { (P value) }\end{array}$ & $\begin{array}{c}1.877 \\
(0.171)\end{array}$ & $\begin{array}{c}0.008 \\
(0.929)\end{array}$ & $\begin{array}{c}2.067 \\
(0.151)\end{array}$ & $\begin{array}{c}8.439 \\
(0.038)\end{array}$ \\
\hline
\end{tabular}

Notes: ${ }^{* * *}=$ significant at $1 \%,{ }^{* *}=$ significant at $5 \%,{ }^{*}=$ significant at $10 \%$. Heteroskedasticity robust standard errors in brackets. Country fixed effects are included in all specifications. Heteroskedasticity robust standard errors in brackets. The Kleibergen-Paap LM statistic is the heteroskedasticity robust test of underidentification. The null hypothesis is that the equation is underidentified. The Hansen J test is the appropriate test of overidentifying restrictions in the presence of heteroskedasticity. The null hypothesis is that all instruments are valid.

The long run coefficients presented in Table 6 further support our results from the static model. In Agriculture most coefficients have a negative sign consistently with the declining trends of this industry. In Manufacturing we again find a positive own TFP effect as well as a positive and significant role of Business Services TFP. Hence, the 
technological complementarity between the two industries finds further support in the dynamic analysis. Similarly, secondary and tertiary skills are important in both sectors while they do not play a significant role in the output shares of Financial Intermediation. Expansion of the latter is significantly related to own productivity improvements as well as larger endowments of ICT capital.

Table 6 - Implied Long-Run Coefficients

\begin{tabular}{lllll}
\hline & Agriculture & Manufacturing & $\begin{array}{c}\text { Financial } \\
\text { Intermediation }\end{array}$ & $\begin{array}{l}\text { Business } \\
\text { Services }\end{array}$ \\
\hline TFP Agriculture & 0.241 & $\mathbf{- 3 . 0 1 5}$ & 0.734 & -0.273 \\
\hline TFP Manufacturing & -0.047 & $\mathbf{9 . 5 1 0}$ & $\mathbf{- 1 . 7 8 3}$ & 0.117 \\
\hline TFP Fin. Intermediation & -0.515 & 0.529 & $\mathbf{1 . 8 3 0}$ & $\mathbf{- 2 . 7 6 2}$ \\
\hline TFP Business Services & -0.209 & $\mathbf{2 . 6 3 8}$ & -0.633 & $\mathbf{4 . 4 0 6}$ \\
\hline ICT capital & -0.351 & $\mathbf{- 6 . 1 1 1}$ & $\mathbf{1 . 9 6 6}$ & -1.032 \\
\hline Non-ICT capital & 2.883 & $\mathbf{- 1 7 . 7 0 7}$ & -2.711 & 3.688 \\
\hline R\&D capital & -3.050 & $\mathbf{3 . 3 1 6}$ & -0.770 & -2.216 \\
\hline Low skill & 0.216 & -0.975 & -1.244 & 0.171 \\
\hline High skill & -3.716 & $\mathbf{5 . 2 2 6}$ & -0.725 & $\mathbf{6 . 8 7 6}$ \\
\hline Energy & 0.891 & $\mathbf{3 . 0 0 8}$ & $\mathbf{- 2 . 2 0 1}$ & $\mathbf{1 . 4 8 3}$ \\
\hline Notes: figures in & &
\end{tabular}

Notes: figures in bold identify significant coefficient estimates, consistent with table 5.

In summary, our results have emphasised the importance of productivity improvements and investments in intangible assets in increasing the shares of the Manufacturing sector. ICT capital has, on the other hand, contributed to the process of de-industrialisation by shifting resources away from Manufacturing and into services. The results for nonICT capital are more complex and unexpected as our analysis reveals that increasing endowments of this factor reduces the shares of Manufacturing. It is possible that allowing for more industry heterogeneity will clarify this result. We leave this development for future research.

\section{Conclusion}

This paper has analysed the determinants of industrial specialisation focusing on the impact of technology and factor endowments, as suggested by the neoclassical theory of international trade. Our empirical model encompasses both the $\mathrm{H}-\mathrm{O}-\mathrm{V}$ and the Ricardian theories of international trade. Overall, our results are consistent with the two theoretical predictions. A noticeable drawback of the existing literature was that no attention had been devoted to the issue of capital 
heterogeneity and to the importance of intangible assets in affecting industries' performance. A key objective of our work has been to incorporate these factors into the analysis. Hence, we have expanded the concept of national factor endowments by accounting for heterogeneous capital assets, namely ICT and non-ICT capital, as well as for the impact of intangible assets such as R\&D and skills. Our results show that own industry TFP is an important determinant of Manufacturing shares and, to a lesser extent, it positively affects output shares in the Financial Intermediation sector. We also find evidence for cross-industry technology effects, which indicate a certain degree of complementarity between productivity improvements in Business Services and sector shares in Manufacturing. From a policy perspective, horizontal policies aimed at increasing productivity will always have a positive impact on sectoral output shares.

Accounting for different capital assets has allowed us to discriminate between different determinants of specialisation in different industries. Our results show that endowments of ICT capital have contributed to the process of de-industrialisation, while $R \& D$ and the availability of an educated labour force play a significant role in expanding the Manufacturing industry. This is consistent with our initial observations of time trends in output shares in countries like Finland, where an increase in the share of Manufacturing in the 1980s was accompanied by increasing investments in R\&D.

The process of de-industrialisation has affected all countries to different extents and the long run consequences of this phenomenon are quite difficult to ascertain. According to the traditional view, exposed by Baumol (1967), labour productivity growth will decline once a country moves away from manufacturing towards the service sector, partly because the service sector is labour intensive and partly because the output in this sector is more difficult to measure. Against this view is the recent US experience where the service sector has been considered the main driver of productivity resurgence in the 1990s (Triplett and Bosworth, 2004; Inklaar et al., 2008) thanks to the adoption of ICT and the implementation of the necessary organisational changes that the new technology has made possible. Our analysis has shown that ICT capital has contributed to the expansion of the Financial Intermediation sector, however we have not found a significant impact in Business Services. This can be explained by the presence of time lags in the adoption of the new technology, as well as institutional rigidities in the European regulatory framework. Therefore, from a policy point of view, an expansion of the Service industry can be attained with further investments in ICT capital and more flexible regulatory framework. However, the Manufacturing sector is R\&D and skill intensive and it is still the main producer of 
innovations. Therefore, the de-industrialisation process can become an issue in the long run if it leads to a decrease in countries' innovative capacities. Our analysis suggests that as long as there are enough resources devoted to increasing the endowments of skills and R\&D this process can be prevented.

Our work has concentrated on four major sectors in seven European countries with similar patterns of growth but it can be easily extended to include a more diversified sample of countries. A further development would be to use a more disaggregated industry structure, looking at individual Manufacturing and Service industries. This will lead to a better understanding of the relationship between heterogeneous capital/intangible assets and the pattern of specialisation. 


\section{Appendix}

\section{Factor Supplies}

The educational database of Barro-Lee reports data on five years average and only up to 1999 . We use a linear interpolation procedure to fill the missing data between years and then we extrapolate data to generate a series up to 2003. There are three categories of educational data for each gender, so we have in total six labour variables.

Values of ICT and non-ICT capital stock converted into international USD dollars with a GDP PPP exchange rate.

Table A1 - Summary of Data Sources

\begin{tabular}{ll}
\hline Period & $\mathbf{1 9 8 0 - 2 0 0 3}$ \\
\hline Countries & Austria, Denmark, Finland, \\
& Germany, Italy, Netherlands, \\
& Portugal, Sweden, UK \\
\hline Sectors ISIC Rev. 3 & Code: \\
& (AtB) Agriculture \\
& (D) Manufacturing \\
& (J) Financial Intermediation \\
& (K) Real Estate Renting and \\
& Business Activities \\
\hline
\end{tabular}

Value added shares: EUKLEMS (2007)

Factor Supplies

Energy: production of energy converted into KG of oil equivalent. Data are taken from the Energy Agency

Capital: Stock of non-ICT and ICT capital taken form EUKLEMS database

Labour-Barro and Lee Data set:

Percentage share of population with primary education

Percentage share of population with secondary education

Percentage share of population with tertiary education

World Development Indicators:

Male and Female population

OECD STAN indicators:

Total R\&D expenditure (GERD)

RTFP and sector prices: Information are obtained from EUKLEMS database GGDC (see section 3.3)

Notes: figures in bold identify significant coefficient estimates, consistent with table 5 . 
Table A2 - Unit Root Tests

\begin{tabular}{|c|c|c|c|c|c|c|}
\hline & $\begin{array}{l}\text { IPS } \\
\text { (1 lag) }\end{array}$ & $\begin{array}{l}\text { IPS } \\
\text { ( } 2 \text { lags) }\end{array}$ & $\begin{array}{l}\text { IPS } \\
\text { (3 lags) }\end{array}$ & $\begin{array}{l}\text { IPS trend } \\
\text { (1 lag) }\end{array}$ & $\begin{array}{l}\text { IPS trend } \\
\text { ( } 2 \text { lag) }\end{array}$ & $\begin{array}{l}\text { IPS trend } \\
\text { (3 lag) }\end{array}$ \\
\hline \multicolumn{7}{|c|}{ Value Added Shares } \\
\hline Agriculture & $\begin{array}{l}-0.504 \\
(0.307)\end{array}$ & $\begin{array}{l}-0.928 \\
(0.177)\end{array}$ & $\begin{array}{l}-1.185 \\
(0.118)\end{array}$ & $\begin{array}{l}-0.048 \\
(0.481)\end{array}$ & $\begin{array}{l}0.027 \\
(0.511)\end{array}$ & $\begin{array}{l}0.213 \\
(0.584)\end{array}$ \\
\hline Manufacturing & $\begin{array}{l}-0.591 \\
(0.277)\end{array}$ & $\begin{array}{l}0.839 \\
(0.799) \\
\end{array}$ & $\begin{array}{l}1.483 \\
(0.931) \\
\end{array}$ & $\begin{array}{l}-0.521 \\
(0.301)\end{array}$ & $\begin{array}{l}-0.041 \\
(0.484)\end{array}$ & $\begin{array}{l}0.344 \\
(0.634)\end{array}$ \\
\hline $\begin{array}{l}\text { Financial } \\
\text { Intermediation }\end{array}$ & $\begin{array}{l}1.024 \\
(0.847)\end{array}$ & $\begin{array}{l}1.075 \\
(0.859)\end{array}$ & $\begin{array}{l}-0.128 \\
(0.449)\end{array}$ & $\begin{array}{l}1.249 \\
(0.894)\end{array}$ & $\begin{array}{l}1.648 \\
(0.950)\end{array}$ & $\begin{array}{l}1.309 \\
(0.905)\end{array}$ \\
\hline $\begin{array}{l}\text { Business. } \\
\text { Services }\end{array}$ & $\begin{array}{l}-1.591 \\
(0.056)\end{array}$ & $\begin{array}{l}-1.072 \\
(0.142) \\
\end{array}$ & $\begin{array}{l}-0.406 \\
(0.342) \\
\end{array}$ & $\begin{array}{l}0.0504 \\
(0.522)\end{array}$ & $\begin{array}{l}0.755 \\
(0.775)\end{array}$ & $\begin{array}{l}1.494 \\
(0.932)\end{array}$ \\
\hline \multicolumn{7}{|l|}{ Relative TFP } \\
\hline Agriculture & $\begin{array}{l}-0.024 \\
(0.491) \\
\end{array}$ & $\begin{array}{l}0.899 \\
(0.815) \\
\end{array}$ & $\begin{array}{l}-0.023 \\
(0.491) \\
\end{array}$ & $\begin{array}{l}1.017 \\
(0.845) \\
\end{array}$ & $\begin{array}{l}1.786 \\
(0.963) \\
\end{array}$ & $\begin{array}{l}1.867 \\
(0.969) \\
\end{array}$ \\
\hline Manufacturing & $\begin{array}{l}0.805 \\
(0.790)\end{array}$ & $\begin{array}{l}2.142 \\
(0.984) \\
\end{array}$ & $\begin{array}{l}2.657 \\
(0.996) \\
\end{array}$ & $\begin{array}{l}-1.652 \\
(0.049) \\
\end{array}$ & $\begin{array}{l}0.265 \\
(0.604)\end{array}$ & $\begin{array}{l}1.684 \\
(0.954) \\
\end{array}$ \\
\hline $\begin{array}{l}\text { Financial } \\
\text { Intermediation }\end{array}$ & $\begin{array}{l}-0.816 \\
(0.207)\end{array}$ & $\begin{array}{l}-0.051 \\
(0.480)\end{array}$ & $\begin{array}{l}-2.228 \\
(0.013)\end{array}$ & $\begin{array}{l}-0.474 \\
(0.318)\end{array}$ & $\begin{array}{l}0.389 \\
(0.651)\end{array}$ & $\begin{array}{l}-0.390 \\
(0.348)\end{array}$ \\
\hline $\begin{array}{l}\text { Business. } \\
\text { Services }\end{array}$ & $\begin{array}{l}-1.504 \\
(0.066)\end{array}$ & $\begin{array}{l}-0.288 \\
(0.387) \\
\end{array}$ & $\begin{array}{l}-0.145 \\
(0.442)\end{array}$ & $\begin{array}{l}0.101 \\
(0.540)\end{array}$ & $\begin{array}{l}0.843 \\
(0.800)\end{array}$ & $\begin{array}{l}0.446 \\
(0.672)\end{array}$ \\
\hline \multicolumn{7}{|l|}{ Factor supplies } \\
\hline Energy & $\begin{array}{l}-0.876 \\
(0.191) \\
\end{array}$ & $\begin{array}{l}-0.825 \\
(0.205) \\
\end{array}$ & $\begin{array}{l}-1.076 \\
(0.141) \\
\end{array}$ & $\begin{array}{l}1.257 \\
(0.896) \\
\end{array}$ & $\begin{array}{l}0.862 \\
(0.806)\end{array}$ & $\begin{array}{l}-0.829 \\
(0.203) \\
\end{array}$ \\
\hline$R \& D$ & $\begin{array}{l}3.743 \\
(1.000)\end{array}$ & $\begin{array}{l}4.484 \\
(1.000) \\
\end{array}$ & $\begin{array}{l}4.653 \\
(1.000) \\
\end{array}$ & $\begin{array}{l}-1.418 \\
(0.078) \\
\end{array}$ & $\begin{array}{l}-1.441 \\
(0.075) \\
\end{array}$ & $\begin{array}{l}-0.869 \\
(0.192) \\
\end{array}$ \\
\hline ICT & $\begin{array}{l}1.100 \\
(0.864)\end{array}$ & $\begin{array}{l}0.610 \\
(0.729) \\
\end{array}$ & $\begin{array}{l}0.956 \\
(0.831)\end{array}$ & $\begin{array}{l}0.011 \\
(0.504)\end{array}$ & $\begin{array}{l}-0.941 \\
(0.173) \\
\end{array}$ & $\begin{array}{l}-0.526 \\
(0.229) \\
\end{array}$ \\
\hline Non ICT & $\begin{array}{l}0.794 \\
(0.786)\end{array}$ & $\begin{array}{l}0.551 \\
(0.709) \\
\end{array}$ & $\begin{array}{l}0.334 \\
(0.631) \\
\end{array}$ & $\begin{array}{l}0.278 \\
(0.610) \\
\end{array}$ & $\begin{array}{l}0.142 \\
(0.556)\end{array}$ & $\begin{array}{l}0.472 \\
(0.682) \\
\end{array}$ \\
\hline Low Skill & $\begin{array}{l}-0.626 \\
(0.266)\end{array}$ & $\begin{array}{l}-1.027 \\
(0.152) \\
\end{array}$ & $\begin{array}{l}-0.753 \\
(0.226)\end{array}$ & $\begin{array}{l}-1.121 \\
(0.131) \\
\end{array}$ & $\begin{array}{l}-1.865 \\
(0.031)\end{array}$ & $\begin{array}{l}-1.238 \\
(0.108) \\
\end{array}$ \\
\hline High Skill & $\begin{array}{l}0.057 \\
(0.523)\end{array}$ & $\begin{array}{l}0.032 \\
(0.513)\end{array}$ & $\begin{array}{l}-0.573 \\
(0.283)\end{array}$ & $\begin{array}{l}-1.279 \\
(0.100)\end{array}$ & $\begin{array}{l}-1.872 \\
(0.031)\end{array}$ & $\begin{array}{l}-1.560 \\
(0.059)\end{array}$ \\
\hline
\end{tabular}

Notes: the table presents the Im et al. (2002) test, with constant and with constant and trend, including up to three lags of the dependent variable. The test is based on the null hypothesis of unit root. P-values are in brackets. 


\section{References}

Autor, D.H., Katz, L.F., \& Krueger, A.B. (1998). Computing Inequality: Have Computers Changed the Labour Market? Quarterly Journal of Economics, 113 (4), 1169-1210. doi:10.1162/003355398555874

Barro, R.J., \& Lee, J.W. (2001). International Data on Educational Attainment: Updates and Implications. Oxford Economic Papers, 53 (3), 541-563. doi:10.1093/oep/53.3.541

Baumol, W. (1967). Macroeconomics of Unbalanced Growth: the Anatomy or Urban Crisis. American Economic Review, 57 (3), 415-426.

Bresnahan, T., Brynjolfsson, E., \& Hitt, L. (2002). Information Technology, Workplace Organization, and the Demand for Skilled Labor: Firm-Level Evidence. Quarterly Journal of Economics, 117 (1), 339-376. doi:10.1162/003355302753399526

Cadot, O., Nicita, A., Sfreddo, C., \& Shakurova, Y. (2007). Endowments, Specialisation and Policy. Working Paper, The Selected Works of Olivier Cadot University of Lausanne, Available at:

http://works.bepress.com/ocadot/13.

Caves, D., Christensen, L., \& Diewert, E. (1982). The Economic Theory of Index Numbers and the Measurement of Input, Output and Productivity. Econometrica, 50 (6), 1393-1414. doi:10.2307/1913388

Clark, C. (1957). The Conditions of Economic Progress. London: Macmillan.

Corrado, C.A., Hulten, C.R., \& Sichel, D.E. (2006). Intangible Capital and Economic Growth. NBER Working Paper n. 11948.

Dixit, A., \& Norman, V. (1980). The Theory of International Trade. Cambridge: Cambridge University Press. doi:10.1017/CBO9780511628627

Dollar, D., \& Wolff, E. (1993). Competitiveness, Convergence and International Specialisation. Cambridge, MA: MIT Press.

Griffith, R., Redding, S., \& Van Reenen, J. (2004). Mapping the Two Faces of R\&D: Productivity Growth in a Panel of OECD Countries. The Review of Economics and Statistics, 86 (4), 883-895. doi:10.1162/0034653043125194

Harrigan, J. (1997). Technology, Factor Supplies, and International Specialisation: Estimating the Neoclassical Model. American Economic Review, 87 (4), 475-494.

Harrigan, J. (1999). Estimation of Cross-Country Differences in Industry Production Functions. Journal of International Economics, 47 (2), 267-293. doi:10.1016/S0022-1996(98)00011-7 
Harrigan, J., (2001). Specialisation and the Volume of Trade: Do Data Obey the Laws? NBER Working Paper, 8675.

Im, K.S., Pesaran, M.H., \& Shin, Y. (2002). Testing for Unit Roots in Heterogeneous Panels. Journal of Econometrics, 115 (1), 53-74. doi:10.1016/S0304-4076(03)00092-7

Inklaar, R., Timmer, M.P., \& van Ark, B. (2008). Market Services Productivity Across Europe and the US. Economic Policy, 23 (53), 139194. doi:10.1111/j.1468-0327.2007.00194.x

Jalava, J., \& Pohjola, M. (2007). ICT as a Source of Output and Productivity Growth in Finland. Telecommunication Policy, 31 (8-9), 463-472. doi:10.1016/j.telpol.2007.05.011

Jorgenson, D.W., Ho, M.S., \& Stiroh, K.J. (2005). Information Technology and the American Growth Resurgence. Cambridge, Massachusetts: The MIT Press.

Jovanovic, B. (1982). Selection and the Evolution of Industry. Econometrica, 50 (3), 649-670. doi:10.2307/1912606

Kohli, U. (1991). Technology, Duality and Foreign Trade. Ann Arbor: University of Michigan Press.

Mason, G., O'Leary, B., \& Vecchi, M. (2010). Certified and Uncertified Skills and Productivity Growth Performance: Cross-Country Evidence at Sectoral Level. NIESR Working Papers, forthcoming.

O' Mahony, M., \& van Ark, B. (2003). EU Productivity and Competitiveness: an Industry Perspective. Luxembourg: Office for Official Publications of the European Communities.

O'Mahony, M., \& Timmer, M.P. (2009). Output, Input and Productivity Measures at the Industry Level: the Euklems Database. Economic Journal, 119 (538), F374-F403. doi:10.1111/j.1468-0297.2009.02280.x

O'Mahony, M. \& Vecchi, M. (2005). Quantifying the Impact of ICT Capital on Output Growth: a Heterogeneous Dynamic Panel Approach. Economica, 72 (288), 615-633. doi:10.1111/j.1468-0335.2005.0435.x

O’Mahony, M., \& Vecchi, M. (2009). R\&D, Knowledge Spillovers and Companies' Productivity Performance. Research Policy, 38 (1), 35-44. doi:10.1016/j.respol.2008.09.003

Redding, S., \& Vera-Martin, M. (2006). Factor Endowments and Production in European Regions. Review of World economics, 141 (1), 132. doi:10.1007/s10290-006-0055-y

Rowthorn, R., \& Ramaswamy, R. (1999). Growth, Trade and Deindustrialization. IMF Staff Papers, 46 (1). 18-41.

Temple, J. (1999). The New Growth Evidence. Journal of Economic Literature, 37 (1), 112-156. 
Timmer, M., Moergastel, T., Stuivenwold, E., \& Ypman, G. (2007). EUKLEMS Growth and Productivity Accounts Version 1.0, from http:/ / www.euklems.net.

Trefler, D. (1995). The Case of Missing Trade and Other Mysteries. American Economic Review, 85 (5), 1029-1046.

Triplett, J.E., \& Bosworth, B.P. (2004). Productivity in the US Services Sector; New Sources of Economic Growth. Washington DC: Brookings Institution.

van Ark, B., \& Pilat, D. (1993). Productivity Levels in Germany, Japan and the United States: Differences and Causes. In M.N., Baily, P.C., Reiss \& C., Winston (Eds.). Brookings Papers on Economic Activity. Macroeconomics 2 (pp. 1-48). Washington D.C.: Brookings Institution Press.

van Ark, B., Inklaar, R., \& McGukin, R.H. (2003). ICT and Productivity in Europe and the United States. Where Do the Differences Come From? CESifo Economic Studies, 49 (3), 295-318. doi:10.1093/cesifo/49.3.295

van Ark, B., O'Mahony, M., \& Timmer, M.P. (2008). The Productivity Gap Between Europe and the US: Trends and Causes. Journal of Economic Perspectives, 22 (1), 25-44. doi:10.1257/jep.22.1.25

Woodland, A. (1982). International Trade and Resource Allocation. Amsterdam and New York: North-Holland and Elsevier Science. 